
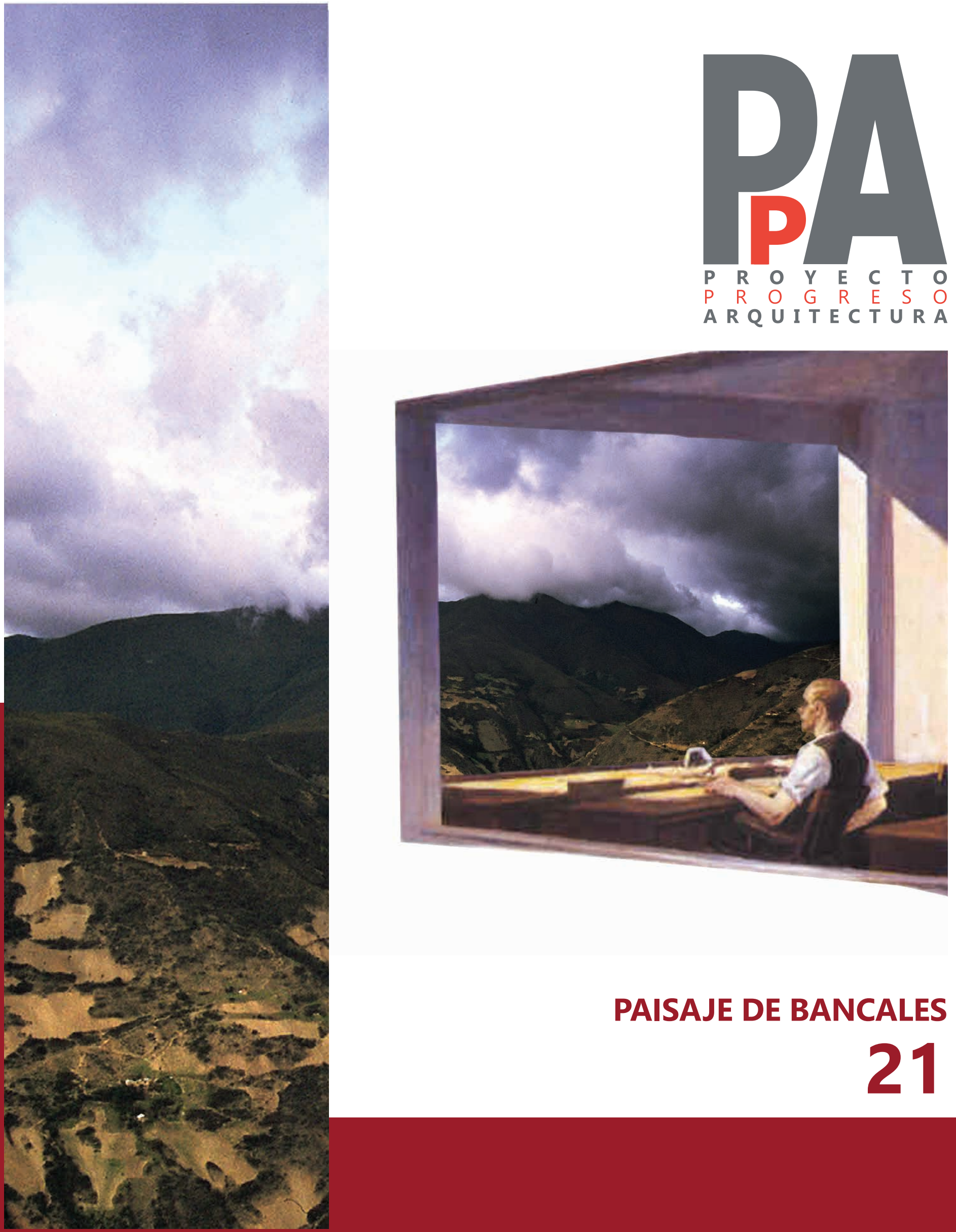

PAISAJE DE BANCALES

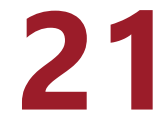




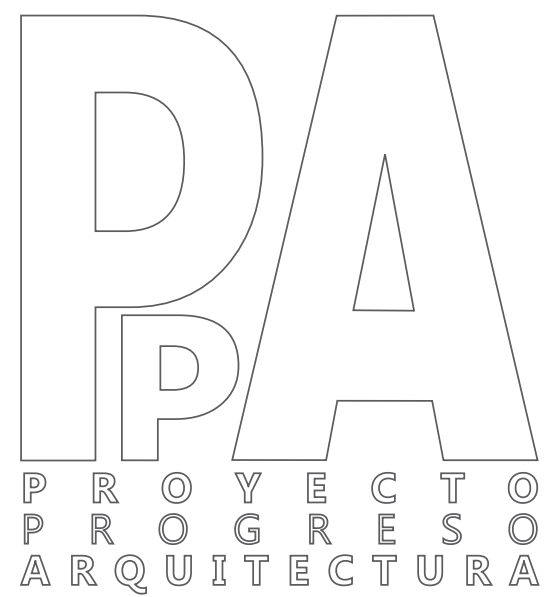

\section{PAISAJE DE BANCALES \\ 21}
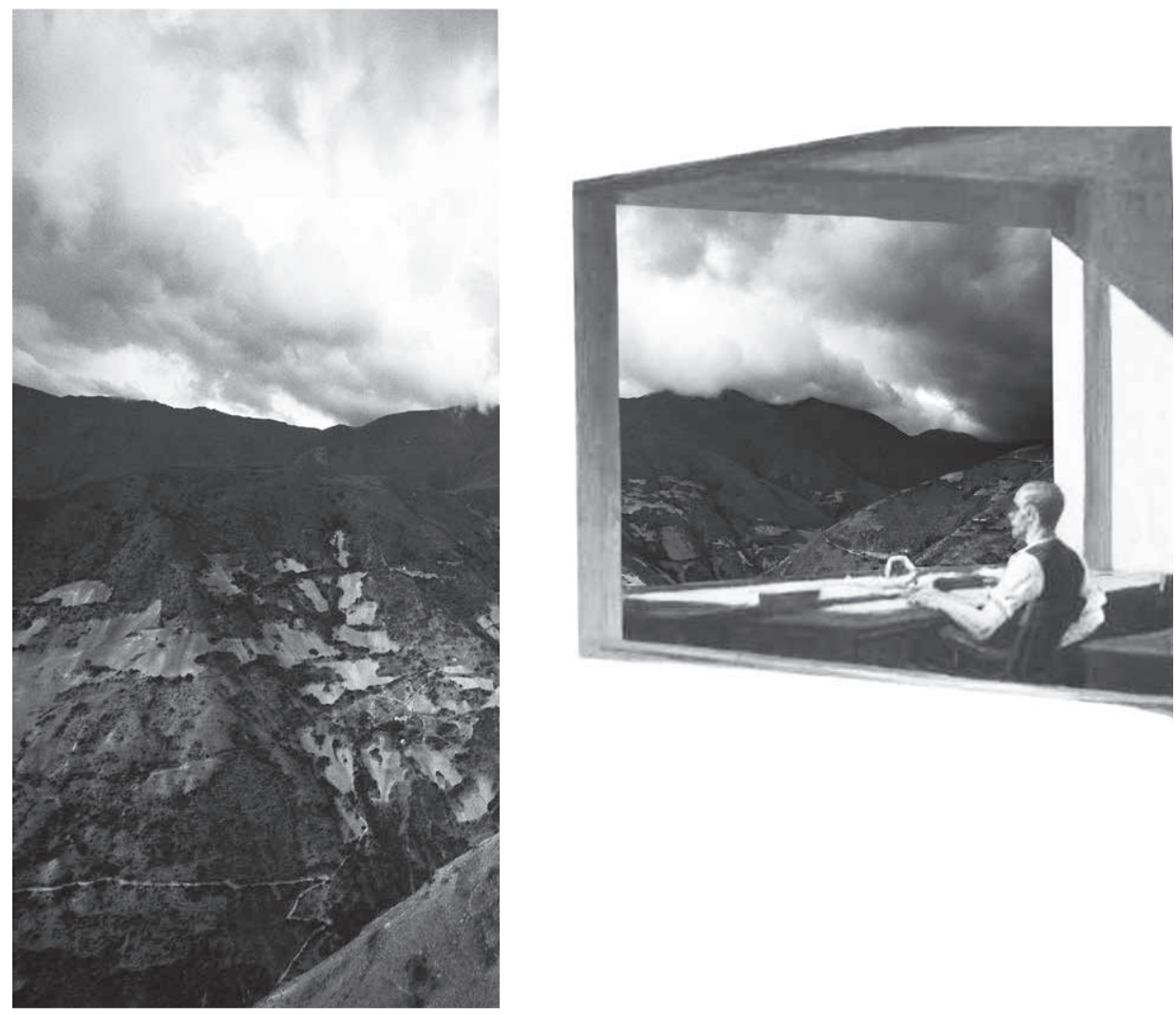


\section{REVISTA PROYECTO PROGRESO ARQUITECTURA}

N22]

\section{paisaje de bancales}
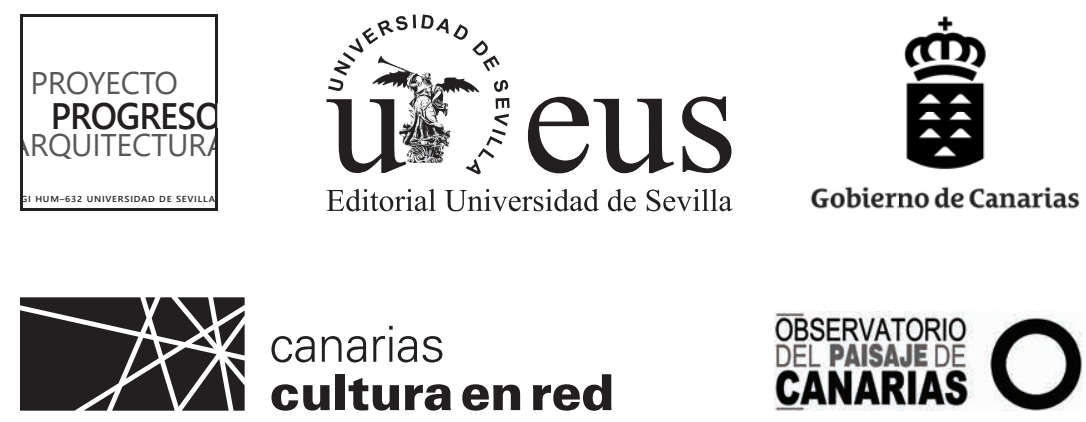
PROYECTO, PROGRESO, ARQUITECTURA. N21, NOVIEMBRE 2019 (AÑO X)

\section{paisaje de bancales}

\section{DIRECCIÓN}

Dr. Amadeo Ramos Carranza. Escuela Técnica Superior de Arquitectura. Universidad de Sevilla. España

\section{SECRETARÍA}

Dra. Rosa María Añón Abajas. Escuela Técnica Superior de Arquitectura. Universidad de Sevilla. España

\section{EQUIPO EDITORIAL}

Edición:

Dr. Amadeo Ramos Carranza. Escuela Técnica Superior de Arquitectura. Universidad de Sevilla. España.

Dra. Rosa María Añón Abajas. Escuela Técnica Superior de Arquitectura. Universidad de Sevilla. España.

Dr. Francisco Javier Montero Fernández. Escuela Técnica Superior de Arquitectura. Universidad de Sevilla. España.

Dr. Alfonso del Pozo Barajas. Escuela Técnica Superior de Arquitectura. Universidad de Sevilla. España.

Dra. Esther Mayoral Campa. Escuela Técnica Superior de Arquitectura. Universidad de Sevilla. España.

Dr. Miguel Ángel de la Cova Morillo-Velarde. Escuela Técnica Superior de Arquitectura. Universidad de Sevilla. España. Dr. Germán López Mena. Escuela Técnica Superior de Arquitectura. Universidad de Sevilla. España.

Juan José López de la Cruz. Escuela Técnica Superior de

Arquitectura. Universidad de Sevilla. España.

Guillermo Pavón Torrejón. Escuela Técnica Superior de Arquitectura. Universidad de Sevilla. España.

Asesores externos a la edición:

Dr. Alberto Altés Arlandis. Post-Doctoral Research Fellow. Architecture Theory Chair . Department of Architecture. TUDelft. Holanda.

Dr. José Altés Bustelo. Escuela Técnica Superior de Arquitectura. Universidad de Valladolid. España.

Dr. José de Coca Leicher. Escuela de Arquitectura y Geodesia. Universidad de Alcalá de Henares. España.

Dr. Jaume J. Ferrer Fores. Escola Tècnica Superior d'Arquitectura de Barcelona. Universitat Politècnica de Catalunya. España.

Dra. Marta Sequeira. CIAUD, Faculdade de Arquitectura da

Universidade de Lisboa, Portugal.

Dr. Carlos Arturo Bell Lemus. Facultad de Arquitectura. Universidad del Atlántico. Colombia.

Carmen Peña de Urquía, architect en RSH-P. Londres. Reino Unido.

SECRETARÍA TÉCNICA

Gloria Rivero Lamela, arquitecto.Personal Investigador en Formación. Universidad de Sevilla. España.

MAQUETA DE LA PORTADA

Miguel Ángel de la Cova Morillo-Velarde

DISEÑO GRÁFICO DE LA MAQUETACIÓN

Maripi Rodríguez

PORTADA:

Del cartel del seminario y de la portada del libro Arquitectura y construcción: el paisaje como argumento(2009). Dir: Ramos-

Carranza, Amadeo; Añón-Abajas, Rosa María

Diseño del cartel: Valentín Trillo Martínez (2007)

ISSN (ed. impresa): 2171-6897

ISSN-e (ed. electrónica): 2173-1616

DOI: http://dx.doi.org/10.12795/ppa

DEPÓSITO LEGAL: SE-2773-2010

PERIOCIDAD DE LA REVISTA: MAYO Y NOVIEMBRE

IMPRIME: PODIPRINT

INICIATIVA DEL GRUPO DE INVESTIGACION HUM-632

"PROYECTO, PROGRESO, ARQUITECTURA"

http://www.proyectoprogresoarquitectura.com
COORDINADOR DE LOS CONTENIDOS CIENTÍFICOS DEL NÚMERO

Dra. Juan Manuel Palerm Salzar. Escuela Técnica Superior de Arquitectura. Universidad de Las Palmas. España.

COMITÉ CIÉNTIFICO

Dr. Gonzalo Díaz Recaséns. Catedrático Proyectos Arquitectónicos. Escuela Técnica Superior de Arquitectura. Universidad de Sevilla. España.

Dr. José Manuel López Peláez. Catedrático Proyectos Arquitectónicos.

Escuela Técnica Superior de Arquitectura. Universidad Politécnica de Madrid. España.

Dr. Víctor Pérez Escolano. Catedrático Historia, Teoría y Composición Arquitectónicas. Escuela Técnica Superior de Arquitectura. Universidad de Sevilla. España.

Dr. Jorge Torres Cueco. Catedrático Proyectos Arquitectónicos. Escuela Técnica Superior de Arquitectura. Universitat Politècnica de València. España. Dr. Armando Dal'Fabbro. Professore Associato. Dipartimento di progettazione architettonica, Facoltà di Architettura, Universitat Instituto Universitario di Architettura di Venezia. Italia.

Dra. Anne-Marie Chatelêt. Professeur Titulaire. Histoire et Cultures Architecturales. École Nationale Supérieure d'Architecture de Stragbourg. Francia.

Dr. ir. Frank van der Hoeven, TU DELFT. Architecture and the Built Environment, Netherlands

EDITA

Editorial Universidad de Sevilla. Sevilla

DIRECCIÓN CORRESPONDENCIA CIENTÍFICA

E.T.S. de Arquitectura. Avda Reina Mercedes, nº 2 41012-Sevilla.

Amadeo Ramos Carranza, Dpto. Proyectos Arquitectónicos.

e-mail: revistappa.direccion@gmail.com

EDICIÓN ON-LINE

Portal informático https://revistascientificas.us.es/index.php/ppa Portalinformático G.I.HUM-632 http://www.proyectoprogresoarquitectura.com Portal informático Editorial Universidad de Sevilla http://www.editorial.us.es/

(C) EDITORIAL UNIVERSIDAD DE SEVILLA, 2019

Calle Porvenir, 27. 41013 SEVILLA. Tfs. 954487447 / 954487451

Fax954487443. [eus4@us.es] [http://www.editorial.us.es]

(c) TEXTOS: SUS AUTORES, 2019.

(c) IMÁGENES: SUS AUTORES Y/O INSTITUCIONES, 2019.

SUSCRIPCIONES, ADQUISICIONES Y CANJE revista PROYECTO, PROGRESO, ARQUITECTURA

Editorial Universidad de Sevilla.

Calle Porvenir, 27. 41013 SEVILLA. Tfs. 954487447 / 954487451

Fax 954487443

Reservados todos los derechos. Ni la totalidad ni parte de esta revista puede reproducirse o transmitirse por ningún procedimiento electrónico o mecánico, incluyendo fotocopia, grabación magnética o cualquier almacenamiento de información y sistema de recuperación, sin permiso escrito de la Editorial Universidad de Sevilla.

Las opiniones y los criterios vertidos por los autores en los artículos firmados son responsabilidad exclusiva de los mismos.

COLABORA DEPARTAMENTO DE PROYECTOS ARQUITECTÓNICOS Escuela Técnica Superior de Arquitectura. Universidad de Sevilla. http://www.departamento.us.es/dpaetsas 


\section{revista PROYECTO, PROGRESO, ARQUITECTURA}

Nuestra revista, fundada en el año 2010, es una iniciativa del Grupo de Investigación de la Universidad de Sevilla HUM-632 "proyecto, progreso, arquitectura" y tiene por objetivo compartir y debatir sobre investigación en arquitectura. Es una publicación científica con periodicidad semestral, en formato papel y digital, que publica trabajos originales que no hayan sido publicados anteriormente en otras revistas. Queda establecido el sistema de arbitraje para la selección de artículos a publicar mediante dos revisores externos -sistema doble ciego- siguiendo los protocolos habituales para publicaciones científicas seriadas. Los títulos, resúmenes ,palabras clave y texto completo de los artículos se publican también en lengua inglesa.

"proyecto, progreso, arquitectura" presenta una estructura clara, sencilla y flexible. Trata todos los temas relacionados con la teoría y la práctica del proyecto arquitectónico. Las distintas "temáticas abiertas" que componen nuestra línea editorial, son las fuentes para la conjunción de investigaciones diversas.

La revista va dirigida a arquitectos, estudiantes, investigadores y profesionales relacionados con el proyecto y la realización de la obra de arquitectura.

Our journal, "proyecto, progreso, arquitectura", founded in 2010, is an initiative of the Research Group HUM-632 of the University of Seville and its objective is the sharing and debating of research within architecture. This six-monthly scientific publication, in paper and digital format, publishes original works that have not been previously published in other journals. The article selection process consists of a double blind system involving two external reviewers, following the usual protocols for serial scientific publications. The titles, summaries, key words and full text of articles are also published in English.

"proyecto, progreso, arquitectura" presents a clear, easy and flexible structure. It deals with all the subjects relating to the theory and the practise of the architectural project. The different "open themes" that compose our editorial line are sources for the conjunction of diverse investigations.

The journal is directed toward architects, students, researchers and professionals related to the planning and the accomplishment of the architectural work.

\section{SISTEMA DE ARBITRAJE}

EVALUACIÓN EXTERNA POR PARES Y ANÓNIMA

El Consejo Editorial de la revista, una vez comprobado que el artículo cumple con las normas relativas a estilo y contenido indicadas en las directrices para los autores, remitirá el artículo a dos expertos revisores anónimos dentro del campo específico de investigación y crítica de arquitectura, según el modelo doble ciego.

Basándose en las recomendaciones de los revisores, el director de la revista comunicará a los autores el resultado motivado de la evaluación por correo electrónico, en la dirección que éstos hayan utilizado para enviar el artículo. El director comunicará al autor principal el resultado de la revisión (publicación sin cambios; publicación con correcciones menores; publicación con correcciones importantes; no aconsejable para su publicación), así como las observaciones y comentarios de los revisores.

Si el manuscrito ha sido aceptado con modificaciones, los autores deberán reenviar una nueva versión del artículo, atendiendo a las demandas y sugerencias de los evaluadores externos. Si lo desean, los autores pueden aportar también una carta al Consejo Editorial en la que indicarán el contenido de las modificaciones del artículo. Los artículos con correcciones importantes podrán ser remitidos al Consejo Asesor y/o Científico para verificar la validez de las modificaciones efectuadas por el autor

EXTERNAL ANONYMOUS PEER REVIEW.

When the Editorial Board of the magazine has verified that the article fulfils the standards relating to style and content indicated in the instructions for authors, the article will be sent to two anonymous experts, within the specific field of architectural investigation and critique, for a double blind review.

The Director of the magazine will communicate the result of the reviewers' evaluations, and their recommendations, to the authors by electronic mail, to the address used to send the article. The Director will communicate the result of the review (publication without changes; publication with minor corrections; publication with significant corrections; its publication is not advisable), as well as the observations and comments of the reviewers, to the main author.

If the manuscript has been accepted with modifications, the authors will have to resubmit a new version of the article, addressing the requirements and suggestions of the external reviewers. If they wish, the authors can also send a letter to the Editorial Board, in which they will indicate the content of the modifications of the article. The articles with significant corrections can be sent to Advisory and/or Scientific Board for verification of the validity of the modifications made by the author.

\section{INSTRUCCIONES A AUTORES PARA LA REMISIÓN DE ARTÍCULOS}

NORMAS DE PUBLICACIÓN

Instrucciones a autores: extensión máxima del artículo, condiciones de diseño -márgenes, encabezados, tipo de letra, cuerpo del texto y de las citas-, composición primera página, forma y dimensión del título y del autor/a, condiciones de la reseña biográfica, del resumen, de las palabras claves, de las citas, de las imágenes -numeración en texto, en pié de imágenes, calidad de la imagen y autoría o procedencia- y de la bibliografía en http://www.proyectoprogresoarquitectura.com (> PARTICIPA > POLITICA DE SECCIONES Y NORMAS DE REDACCIÓN / NORMAS BIBLIOGRAFÍA Y CITAS)

PUBLICATION STANDARDS

Instructions to authors: maximum length of the article, design conditions (margins, headings, font, body of the text and quotations), composition of the front page, form and size of the title and the name of the author, conditions of the biographical review, the summary key words, quotations, images (text numeration, image captions, image quality and authorship or origin) and of the bibliography in http://www.proyectoprogresoarquitectura.com (> PARTICIPA > POLÍTICA DE SECCIONES Y NORMAS DE REDACCIÓN / NORMAS BIBLIOGRAFÍA Y CITAS) 


\section{SERVICIOS DE INFORMACIÓN}

\section{CALIDAD EDITORIAL}

La Editorial Universidad de Sevilla cumple los criterios establecidos por la Comisión Nacional Evaluadora de la Actividad Investigadora para que lo publicado por el mismo sea reconocido como "de impacto" (Ministerio de Ciencia e Innovación, Resolución 18939 de 11 de noviembre de 2008 de la Presidencia de la CNEAI, Apéndice I, BOE nº 282, de 22.11.08).

La Editorial Universidad de Sevilla forma parte de la U.N.E. (Unión de Editoriales Universitarias Españolas) ajustándose al sistema de control de calidad que garantiza el prestigio e internacionalidad de sus publicaciones.

\section{PUBLICATION QUALITY}

The Editorial Universidad de Sevilla fulfils the criteria established by the National Commission for the Evaluation of Research Activity (CNEAl) so that its publications are recognised as "of impact" (Ministry of Science and Innovation, Resolution 18939 of 11 November 2008 on the Presidency of the CNEAl, Appendix I, BOE No 282, of 22.11.08).

The Editorial Universidad de Sevilla operates a quality control system which ensures the prestige and international nature of its publications, and is a member of the U.N.E. (Unión de Editoriales Universitarias Españolas-Union of Spanish University Publishers).

Los contenidos de la revista PROYECTO, PROGRESO, ARQUITECTURA aparecen en:

\section{bases de datos: indexación}

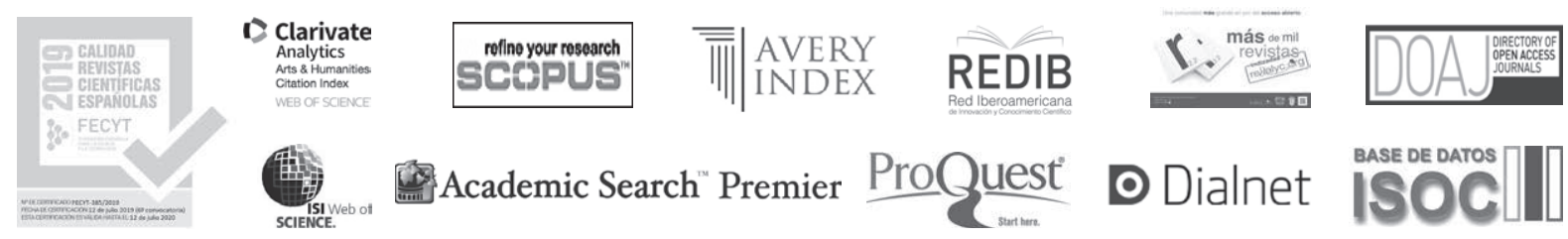

\section{SELLO DE CALIDAD EDITORIAL FECYT 2019}

WoS. Arts \& Humanities Citation Index WoS. ESCl - Emerging Sources Citation Index SCOPUS

AVERY. Avery Index to Architectural Periodicals

REBID. Red Iberoamericana de Innovación y Conocimiento Científico

REDALYC. Red de Revistas Científicas de América Latina y el Caribe, España y Portugal.

EBSCO. Fuente Académica Premier

EBSCO. Art Source

DOAJ, Directory of Open Access Journals

PROQUEST (Arts \& Humanities, full text)

DIALNET

ISOC (Producida por el CCHS del CSIC)

DRIJ. Directory of Research Journals Indexing

SJR (2018): 0.111, H index: 2 CUARTIL: Q3

\section{catalogaciones: criterios de calidad}

RESH (Revistas Españolas de Ciencias Sociales y Humanidades).

Catálogos CNEAI (16 criterios de 19). ANECA (18 criterios de 21). LATINDEX (35 criterios sobre 36).

DICE (CCHS del CSIC, ANECA)

MIAR, Matriu d'Informació per a l'Avaluació de Revistes. IDCS 2018: 10,500. Campo ARQUITECTURA

CLASIFICACIÓN INTEGRADA DE REVISTAS CIENTÍFICAS (CIRC-CSIC): A

ERIHPLUS

SCIRUS, for Scientific Information.

ULRICH'S WEB, Global Serials Directory.

ACTUALIDAD IBEROAMERICANA.

catálogos on-line bibliotecas notables de arquitectura:

CLIO. Catálogo on-line. Columbia University. New York

HOLLIS. Catálogo on-line. Harvard University. Cambridge. MA

SBD. Sistema Bibliotecario e Documentale. Instituto Universitario di Architettura di Venezia

OPAC. Servizi Bibliotecari di Ateneo. Biblioteca Centrale. Politecnico di Milano

COPAC. Catálogo colectivo (Reino Unido)

SUDOC. Catálogo colectivo (Francia)

ZBD. Catálogo colectivo (Alemania)

REBIUN. Catálogo colectivo (España)

OCLC. WorldCat (Mundial) 


\section{DECLARACIÓN ÉTICA SOBRE PUBLICACIÓN Y MALAS PRÁCTICAS}

La revista PROYECTO, PROGRESO, ARQUITECTURA (PPA) está comprometida con la comunidad académica en garantizar la ética y calidad de los artículos publicados. Nuestra revista tiene como referencia el Código de Conducta y Buenas Prácticas que, para editores de revistas científicas, define el COMITÉ DE ÉTICA DE PUBLICACIONES (COPE).

Así nuestra revista garantiza la adecuada respuesta a las necesidades de los lectores y autores, asegurando la calidad de lo publicado, protegiendo y respetando el contenido de los artículos y la integridad de los mismo. El Consejo Editorial se compromete a publicar las correcciones, aclaraciones, retracciones y disculpas cuando sea preciso.

En cumplimiento de estas buenas prácticas, la revista PPA tiene publicado el sistema de arbitraje que sigue para la selección de artículos así como los criterios de evaluación que deben aplicar los evaluadores externos -anónimos y por pares, ajenos al Consejo Editorial-. La revista PPA mantiene actualizados estos criterios, basados exclusivamente en la relevancia científica del artículo, originalidad, claridad y pertinencia del trabajo presentado.

Nuestra revista garantiza en todo momento la condifencialidad del proceso de evaluación: el anonimato de los evaluadores y de los autores; el contenido evaluado; los informes razonados emitidos por los evaluadores y cualquier otra comunicación emitida por los consejos Editorial, Asesor y Científico si así procediese.

Igualmente quedan afectados de la máxima confidencialidad las posibles aclaraciones, reclamaciones o quejas que un autor desee remitir a los comités de la revista o a los evaluadores del artículo.

La revista PROYECTO, PROGRESO, ARQUITECTURA (PPA) declara su compromiso por el respeto e integridad de los trabajos ya publicados. Por esta razón, el plagio está estrictamente prohibido y los textos que se identifiquen como plagio o su contenido sea fraudulento, serán eliminados o no publicados por la revista PPA. La revista actuará en estos casos con la mayor celeridad posible. Al aceptar los términos y acuerdos expresados por nuestra revista, los autores han de garantizar que el artículo y los materiales asociados a él son originales o no infringen derechos de autor. También los autores tienen que justificar que, en caso de una autoría compartida, hubo un consenso pleno de todos los autores afectados y que no ha sido presentado ni publicado con anterioridad en otro medio de difusión.

\section{ETHICS STATEMENT ON PUBLICATION AND BAD PRACTICES}

PROYECTO, PROGRESO ARQUITECTURA (PPA) makes a commitment to the academic community by ensuring the ethics and quality of its published articles. As a benchmark, our journal uses the Code of Conduct and Good Practices which, for scientific journals, is defined for editors by the PUBLICATION ETHICS COMMITTEE (COPE).

Our journal thereby guarantees an appropriate response to the needs of readers and authors, ensuring the quality of the published work, protecting and respecting the content and integrity of the articles. The Editorial Board will publish corrections, clarifications, retractions and apologies when necessary.

In compliance with these best practices, PPA has published the arbitration system that is followed for the selection of articles as well as the evaluation criteria to be applied by the anonymous, external peer-reviewers. PPA keeps these criteria current, based solely on the scientific importance, the originality, clarity and relevance of the presented article.

Our journal guarantees the confidentiality of the evaluation process at all times: the anonymity of the reviewers and authors; the reviewed content; the reasoned report issued by the reviewers and any other communication issued by the editorial, advisory and scientific boards as required.

Equally, the strictest confidentiality applies to possible clarifications, claims or complaints that an author may wish to refer to the journal's committees or the article reviewers.

PROYECTO, PROGRESO ARQUITECTURA (PPA) declares its commitment to the respect and integrity of work already published. For this reason, plagiarism is strictly prohibited and texts that are identified as being plagiarized, or having fraudulent content, will be eliminated or not published in PPA. The journal will act as quickly as possible in such cases. In accepting the terms and conditions expressed by our journal, authors must guarantee that the article and the materials associated with it are original and do not infringe copyright. The authors will also have to warrant that, in the case of joint authorship, there has been full consensus of all authors concerned and that the article has not been submitted to, or previously published in, any other media. 
PROYECTO, PROGRESO, ARQUITECTURA. N21, NOVIEMBRE 2019 (AÑO X)

\section{paisaje de bancales}

índice

editorial

ARQUITECTURA DE LA MONÓTONA REPETICIÓN. PAISAJE DE BANCALES / ARCHITECTURE OF THE MONOTTON REPETITION. TERRACES LANDSCAPES

Juan Manuel Palerm Salazar - (DOI: http://dx.doi.org/10.12795/ppa.2019.121.12

entre líneas

ATAPTED SLOPES

Lucija Ažman Momirskis - (DOl: http://dx.doi.org/10.12795/ppa.2019.i21.01)

artículos

BANCALES HABITADOS: DE LA REUTILIZACIÓN EN LA ARQUITECTURA TRADICIONAL AL TRABAJO CON EL TIEMPO DE CÉSAR MANRIQUE Y SOUTO DE MOURA / FLIVING TERRACES: FROM REUSE IN TRADITIONAL ARCHITECTURE TO CÉSAR MANRIQUE AND SOUTO DE MOURA'S WORK WITH TIME

Francisco Javier Castellano Pulido - (DOI: http://dx.doi.org/10.12795/ppa.2019.121.02)

ESTRATEGIAS TERRITORIALES INTEGRALES PARA LA PUESTA EN VALOR DE PAISAJE CULTURAL AGRÍCOLA. LA RIBEIRA SACRA, GALICIA, ESPAÑA / COMPREHENSIVE TERRITORIAL STRATEGIES TO ENHANCE THE AGRICULTURAL-CULTURAL LANDSCAPE. RIBEIRA SACRA, GALICIA, SPAIN

Susana López Varela - (D0I: http://dx.doi.org/10.12795/ppa.2019.i21.03)

PAISAJES DE ALTURA: LOS ANDENES DEL DISTRITO DE CABANA, VALLE DEL SONDONDO, PERÚ / HIGH LANDSCAPES: THE ANDENES OF THE DISTRIT OF CABANA, SONDONDO VALLEY, PERU Sonia Delgado Berrocal - (DOl: http://dx.doi.org/10.12795/ppa.2019.i21.04)

COLTIVARE I TERRAZZAMENTI AI PIEDI DEL MONTE BIANCO. LA "VITICOLTURA EROICA" DI MORGEX / CULTIVATING THE TERRACES AT THE FOOT OF MONT BLANC. THE "HEROIC VITICULTURE" OF MORGEX

Beatrice Agulli - (DOl: http://dx.doi.org/10.12795/ppa.2019.121.05)

SIAH DAREH. TERRAZAS Y PAISAJE EN ABBAS KIAROSTAMI / SIAH DAREH. TERRACES AND LANDSCAPE IN ABBAS KIAROSTAMI

Pablo López Santana - (DOl: http://dx.doi.org/10.12795/ppa.2019.121.06)

FRANK LLOYD WRIGHT. TRABAJAR LA TIERRA PARA UN PAISAJE SIMBIÓTICO / FRANK LLOYD WRIGHT. EARTHWORK FOR A SYMBIOTIC LANDSCAPE

José María Jové Sandoval - (D0l: http://dx.doi.org/10.12795/ppa.2019.i21.07)

ROGELIO SALMONA Y LA CONSTRUCCIÓN DEL LÍMITE. DIÁLOGOS ENTRE TOPOGRAFÍA Y PAISAJE / ROGELIO SALMONA AND THE CONSTRUCTION OF LIMITS. DIALOGUES BETWEEN TOPOGRAPHY AND LANDSCAPE

Clara Mejía Vallejo; Ricardo Merí de la Maza - (D0l: http://dx.doi.org/10.12795/ppa.2019.i21.08)

reseña bibliográfica TEXTOS VIVOS

RODRIGO ALMONACID CANSECO: EL PAISAJE CODIFICADO EN LA ARQUITECTURA DE ARNE JACOBSEN

Carlos Santamarina-Macho - (DOI: http://dx.doi.org/10.12795/ppa.2019.i21.09)

JAVIER MADERUELO: EL PAISAJE. GÉNESIS DE UN CONCEPTO

Victoriano Sainz Gutiérrez - (DOI: http://dx.doi.org/10.12795/ppa.2019.121.10)

GEORG SIMMEL: FILOSOFÍA DEL PAISAJE

Esther Mayoral Campa - (DOI: http://dx.doi.org/10.12795/ppa.2019.i21.11)

VERSIÓN EN INGLÉS A TEXTO COMPLETO DE TODOS LOS ARTICULOS, EN LA EDICIÓN ON-LINE https://revistascientificas.us.es/index.php/ppa y http://www.proyectoprogresoarquitectura.com/ 

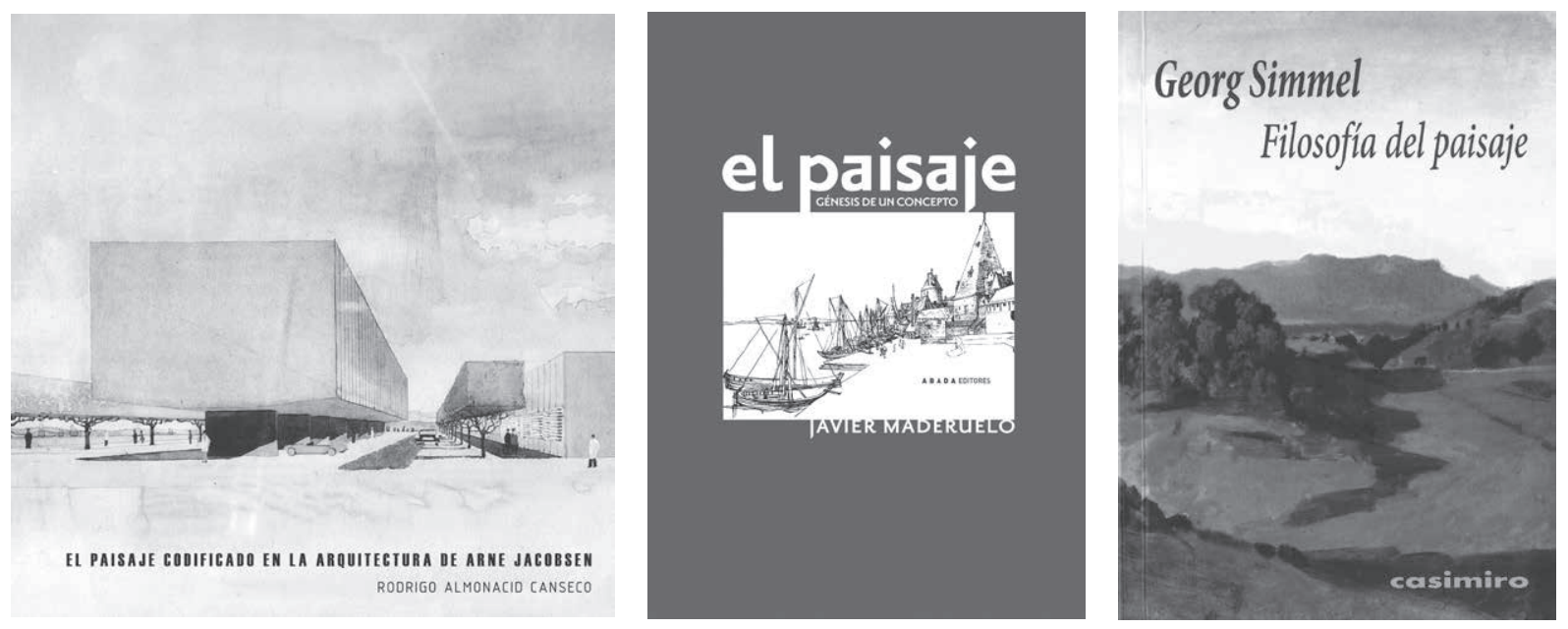

\section{reseña bibliográfica TEXTOS VIVOS}

Nuestra época está sometida a transformaciones hasta ahora insospechadas a cuya aparición no somos ajenos y que afectan a la forma de entender y practicar la arquitectura.

El entendimiento y la acción en la nueva arquitectura no deben abordarse solo desde la racionalidad del proyecto sino desde la reconstrucción crítica de la memoria de nuestra cultura y de nuestra participación en ella a lo largo del tiempo y en la evolución de la sociedad.

Cada tiempo, y el nuestro también, decide qué arquitectos y cuáles textos y obras han de ser rescatados y recalificados como clásicos.

Mediante el diálogo con ellos, los arquitectos actuales nos alinearemos en la tradición arquitectónica de la que, hoy, de manera perentoria, no es posible ni razonable prescindir. PROYECTO, PROGRESO, ARQUITECTURA destina esta sección a realizar un repaso propositivo y abierto a esos textos. 


\title{
JAVIER MADERUELO: EL PAISAJE. GÉNESIS DE UN CONCEPTO
}

\author{
Madrid: Abada, 2005. 341 páginas, formato 16 × 23,5 cm. ISBN 84-96258-56-4
}

Victoriano Sainz Gutiérrez (https://orcid.org/0000-0002-8125-5333)

Dr. arquitecto, profesor titular del Departamento de Urbanística y Ordenación del Territorio, Escuela Técnica Superior de Arquitectura, Universidad de Sevilla, España

Persona de contacto: vsainz@us.es

E I paisaje es, sin duda, un concepto emergente tanto en la arquitectura como en el urbanismo contemporáneos, que han desarrollado una extraordinaria sensibilidad para las cuestiones relacionadas con su construcción a través del proyecto. Y es que si antaño el paisaje aparecía como algo dado, casi natural, que era objeto de representación para su contemplación estética, ahora buscamos sobre todo construir paisajes que puedan ser vividos, usados y disfrutados. El origen de este interés constructivo por el paisaje probablemente esté relacionado con el papel desempeñado por el diseño de parques y jardines en el desarrollo de la ciudad moderna, donde las prácticas vinculadas al espacio dependen menos de lo visual que de un tipo de experiencia más compleja que — como ya dijera Simmel— resulta del rápido e ininterrumpido intercambio de impresiones internas y externas.

Esta evolución en el modo de entender el paisaje conduce de manera casi inevitable a investigar su historia, y dicha investigación debe comenzar, claro está, por el origen del concepto: cuándo y por qué surgió la necesidad de ese constructo cultural que nos llevaría a establecer, a través de la mirada, una concreta relación con el entorno que habitamos, llegando a convertirse en una de las grandes ideas sobre las que apoya toda la cultura. La cuestión ha sido analizada por uno de nuestros mayores expertos en el tema, el arquitecto, crítico y profesor Javier Maderuelo, en un texto destinado a convertirse en un clásico de los estudios sobre el paisaje. Nacido de su tesis doctoral en Historia del Arte, el libro que aquí se reseña es el resultado de una década de trabajo dedicada al particular e inaugura una fecunda trayectoria orientada en esa dirección, cuyos frutos están a la vista.

Habida cuenta de que el término paisaje nació en el ámbito de la pintura, Maderuelo hace un recorrido por la historia del arte que abarca cronológicamente desde la Roma antigua hasta comienzos del siglo XVII, cuando aparecen en Holanda los primeros paisajes propiamente dichos, independientes de la pintura que pretendía narrar una historia, originando así un nuevo género. En palabras de su autor, el libro está planteado como "una historia de la mirada, es decir, como una historia del esfuerzo de aprendizaje visual y de la evolución en las interpretaciones que el hombre ha tenido que experimentar a lo largo de muchos siglos para comprender el mundo que le rodea". Para trazar esa historia se llevan a cabo numerosas incursiones en terrenos que resultan colaterales al dibujo y la pintura, como la filosofía, la religión, la arquitectura, la jardinería, la cartografía y, en general, el mundo de las ideas, pero sin los cuales es difícil entender hasta los motivos de fondo que pueden haber conducido al surgimiento del concepto de paisaje.

No resulta posible sintetizar aquí todo el amplísimo ejercicio de erudición que Maderuelo despliega para detallar las distintas etapas que ha recorrido la cultura occidental hasta llegar al momento en que apareció el paisaje como género pictórico. Me limitaré a subrayar los aspectos de ese proceso más directamente relacionados con las temáticas específicas de esta revista, porque pueden dar una idea del interés del libro para situar en su contexto las cuestiones contemporáneas relacionadas con el paisajismo. Y es que - como se explica en el primer capítulo, dedicado a definir el concepto de paisaje — la arquitectura, la ciudad y el territorio conforman el marco físico que le sirve de sustrato, luego leído e interpretado por nuestra mirada para proceder a la construcción de esa imagen sintética que va más allá de los elementos que la componen, ya no ligada a la significación aislada de cada uno de ellos ni formada mecánicamente a partir de ellos; de ahí nace nuestra consciencia del paisaje.

En su recorrido por la génesis de la idea de paisaje, Maderuelo arranca del mundo antiguo, deteniéndose en la cultura romana, donde cree encontrar un modo de vida rústica vinculada al otium que se situaría a las puertas del concepto de mismo de paisaje. Augustin Berque ha sostenido que la llegada del cristianismo —-más concretamente, el pensamiento agustiniano_ impidió que madurase ese concepto, pero la tesis es arriesgada. Parece más probable que fuera la progresiva ruralización de la sociedad tardorromana, que condujo al fin de la cultura urbana antigua, la causante de este hecho. En todo caso, no es tanto en la obra 
del obispo de Hipona como en la literatura vinculada a la aparición del monacato cristiano donde habría que buscar el cambio en el modo de percibir el entorno natural; puede verse a este respecto la distancia que media entre las Bucólicas de Virgilio y la Vita Antonii de Atanasio.

De hecho, solo con el renacimiento urbano, potenciado por la recuperación de la actividad comercial asociada al otoño de la Edad Media, se produce eso que Maderuelo llama "el despertar de los sentidos", es decir, la emergencia de un nuevo naturalismo, del que serán testigos Francisco de Asís, Petrarca o Boccaccio, por referirme a algunos de los autores mencionados en el libro. Es este contexto el que acaba posibilitando la aparición de las villas mediceas —en especial, las construidas por Michelozzo—, que manifiestan una mirada diferente en relación con el medio rústico, caracterizada por la búsqueda de una contemplación desinteresada y placentera del territorio circundante; en especial, la de Fiésole, situada a media ladera, que permite disfrutar desde sus amplias logias de un despejado panorama de la Toscana.

No obstante, esta nueva cultura visual propia del Renacimiento, desarrollada en gran parte gracias al descubrimiento de la perspectiva, afectará por igual a lo urbano y a lo territorial. Maderuelo lo ilustra acudiendo al ejemplo tal vez más insigne y arquetípico, el de Pienza. Allí, sobre el solar de la antigua casa familiar, el humanista Eneas Silvio Piccolomini, convertido en papa con el nombre de Pío II, hace construir un conjunto urbano que integra una pluralidad de miradas. Las historias de la arquitectura se suelen detener en el espacio del poder constituido por la plaza creada por la catedral y los tres palacios que la flanquean, pero más relevante aún para nuestro asunto es la relación que el palacio familiar establece con el entorno natural: a través del jardín, que puede ser intuido desde la calle, y mediante las magníficas vistas del valle del Orcia que, desde el balcón que supone la doble logia de la fachada trasera del edificio, es posible disfrutar.

Como ya viera Benevolo, "por primera vez un conjunto monumental de este género está ligado orgánicamente a un espacio verde y a una panorámica paisajista". Pero era solo el comienzo; una nueva vuelta de tuerca en esta dirección le corresponde, en el entorno véneto, a Palladio con sus célebres villas, capaces de articular de manera asombrosamente eficaz la imagen patricia, el uso agrícola y la integración en el medio natural. Estaba construyendo con ello una nueva relación entre arquitectura y lugar, que después sería trasladada a otros entornos geográficos por los arquitectos británicos de matriz palladiana. En este sentido, Maderuelo señala acertadamente la notable aportación que, desde la arquitectura, el maestro vicentino hizo a la creación de una cultura paisajista.

El último eslabón que Maderuelo señala en su historia de la mirada, antes de llegar a los paisajes holandeses de comienzos del siglo XVII, está relacionado con la emergencia de esa imagen geográfica del mundo posibilitada por los grandes descubrimientos, los cuales, a su vez, no pueden ser desligados del desarrollo de nuevos modos de representación asociados a la corografía. Las colecciones de vistas de ciudades de Hoefnagel o de Van den Wyngaerde, nacidas del interés científico por conocer con detalle y exactitud los dominios de cada Estado, iban, sin duda, a proporcionar también un deseo de dejar constancia de las emociones y las vivencias asociadas a esos entornos urbano-territoriales. Asistimos con ello a la aparición de unas vistas — como las de Haarlem realizadas por Suycker, Vroom y Ruysdael— ya no asociadas al poder, sino al disfrute personal de unos espacios ligados a la propia vida cotidiana y, en cuanto tales, depositarios de la memoria individual y colectiva.

Son, sin duda, muchos otros los puntos de interés del libro, que invito al lector interesado a descubrir y disfrutar por su cuenta. Con esta reseña solo he querido dejar constancia de la importancia de la compleja tarea abordada por Maderuelo, pues solo una historia del paisaje nos permitirá comprender cómo hemos llegado a la democratización contemporánea del mismo, llevada a cabo a través de propuestas como la de Gilles Clément, de la que ya quedó constancia en un número anterior de esta misma sección de la revista. 

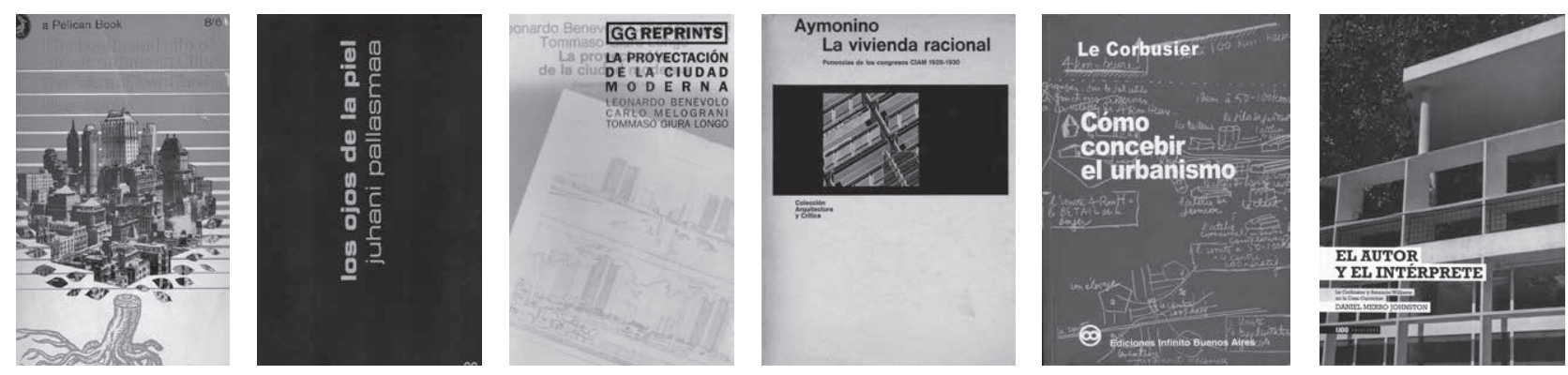

PPA N04: Jane Jacobs: MUERTE Y VIDA DE LAS GRANDES CIUDADES - Juhani Pallasmaa: LOS OJOS DE LA PIEL. LA ARQUITECTURA DE LOS SENTIDOS - Leonardo Benevolo et alt: LA PROYECTACIÓN DE LA CIUDAD MODERNA / PPA N05: Carlo Aymonino: LA VIVIENDA RACIONAL. PONENCIAS DE LOS CONGRESOS CIAM - Le Corbusier: CÓMO CONCEBIR EL URBANISMO - Daniel Merro Johnston: EL AUTOR Y EL INTÉRPRETE. LE CORBUSIER Y AMANCIO WILLIMAS EN LA CASA CURUTCHET
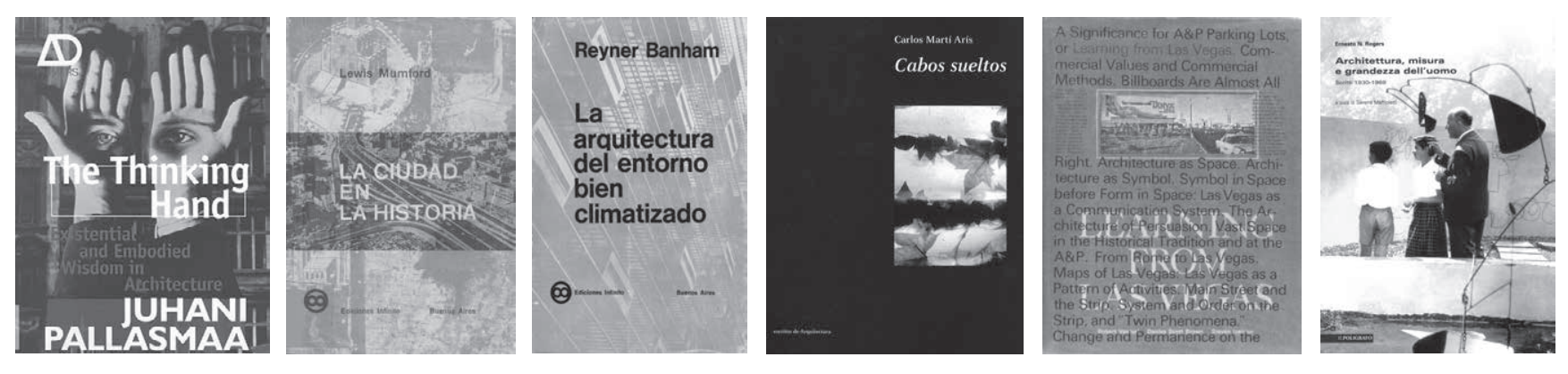

PPA N06: Juhani Pallasmaa: THE THINKING HAND: EXISTENTIAL AND EMBOIDIED WISDOM IN ARCHITECTURE - Lewis Mumford: LA CIUDAD EN LA HISTORIA. SUS ORÍGENES, TRANSFORMACIONES Y PERSPECTIVAS - Reyner Banham: LA ARQUITECTURA DEL ENTORNO BIEN CLIMATIZADO / PPA N07: Carlos Martí Arís: CABOS SUELTOS / PPA N08: Robert Venturi, Denise Scott Brown y Steven Izenour: LEARNING FROM LAS VEGAS / Serena Mafioletti: ARCHITTETURA, MISURA E GRANDEZA DELL'UOMO. SCRITTI 1930-1969
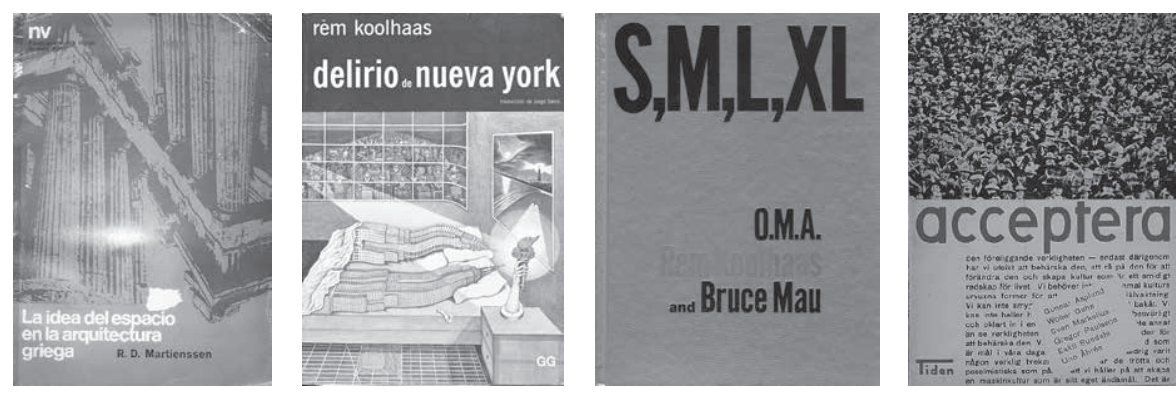

PPA N09: R. D. Martienssen: LA IDEA DEL ESPACIO EN LA ARQUITECTURA GRIEGA / PPA N10: Rem Koolhaas: SMALL, MEDIUM, LARGE, EXTRA-LARGE - Rem Koolhaas: DELIRIO DE NUEVA YORK. UN MANIFIESTO RETROACTIVO PARA MANHATTAN / PPA N11: G. Asplund, W. Gahn, S. Markelius, G. Paulsson, E. Sundahl, U. Åhrén: ACCEPTERA 

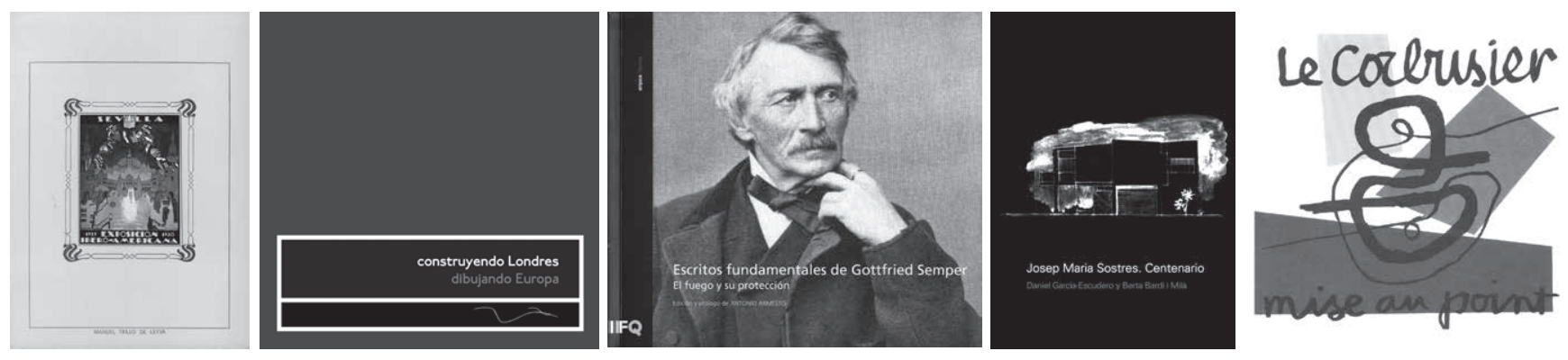

PPA N12: Manuel Trillo de Leyva: LA EXPOSICIÓN IBEROAMERICANA: LA TRANSFORMACIÓN URBANA DE SEVILLA - Manuel Trillo de Leyva: CONSTRUYENDO LONDRES; DIBUJANDO EUROPA / PPA N13: Antonio Armesto (Ed. y Prol.): ESCRITOS FUNDAMENTALES DE GOTTFRIED SEMPER. EL FUEGO Y SU PROTECCIÓN - Daniel García-Escudero y Berta Bardí i milà (Comps.): JOSÉ MARÍA SOSTRES. CENTENARIO - Jorge Torres Cueco (Trad.): LE CORBUSIER. MISE AU POINT
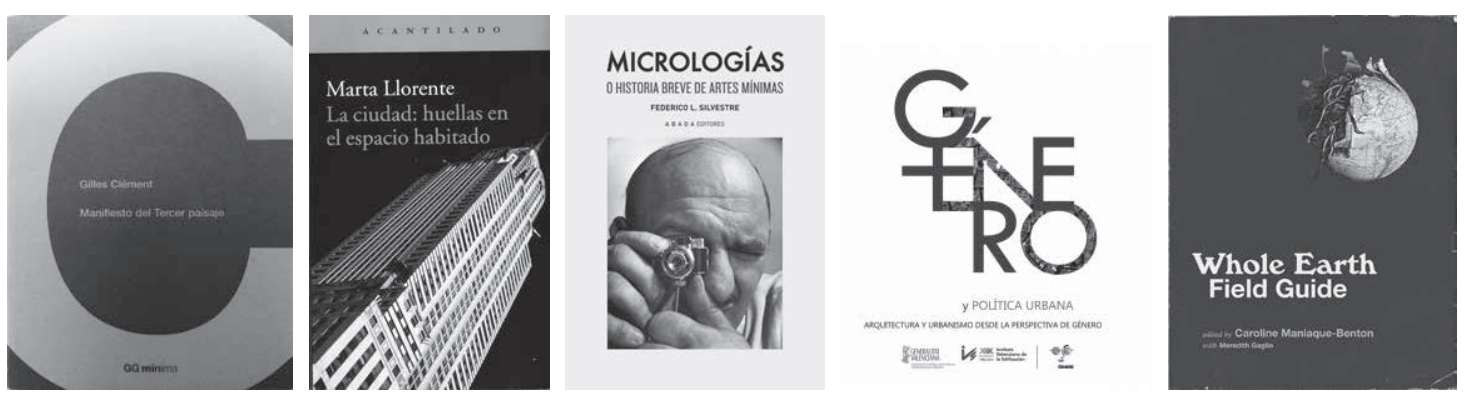

PPA N14: Gilles Clément: MANIFIESTO DEL TERCER PAISAJEERA - Marta Llorente Díaz: LA CIUDAD: HUELLAS EN EL ESPACIO HABITADO / PPA N15: Federico López Silvestre: MICROLOGÍAS O BREVE HISTORIA DE ARTES MÍNIMAS / PPA N16: Begoña Serrano Lanzarote; Carolina Mateo Cecilia; Alberto Rubio Garrido (ED.): GÉNERO Y POLÍTICA URBANA. ARQUITECTURA Y URBANISMODESDE LA PERSPECTIVA DE GÉNERO - Caroline Maniaque-Benton with Merodith Gaglio (EDS.) WHOLE EARTH FIELD GUIDE
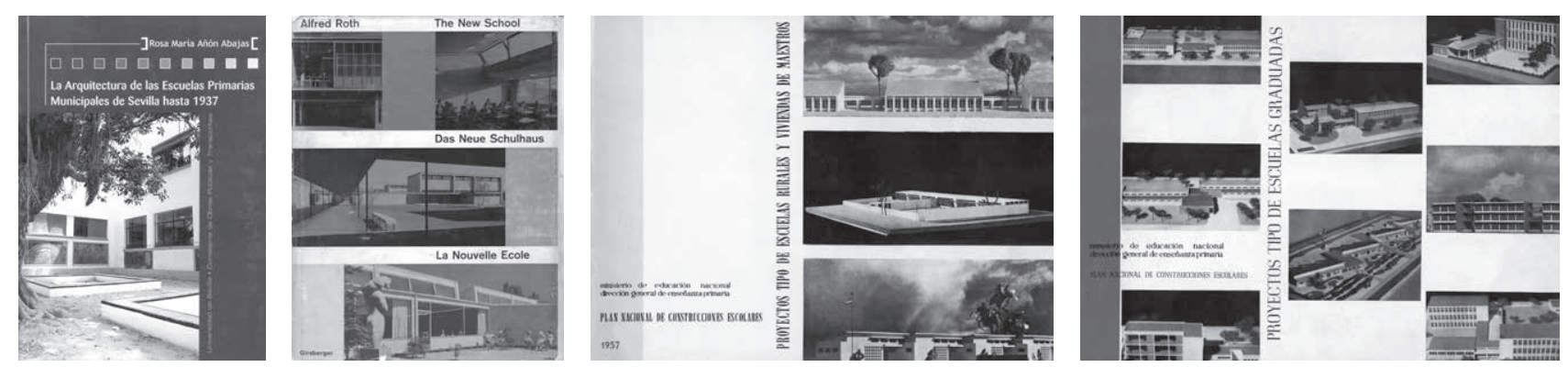

PPA N17: Rosa María Añón Abajas: LA ARQUITECTURA DE LAS ESCUELAS PRIMARIAS MUNICIPALES DE SEVILLA HASTA 1937 - Alfred Roth: THE NEW SCHOOL - PLAN NACIONAL DE CONSTRUCCIONES ESCOLARES (VOLUMEN I) PROYECTOS TIPO DE ESCUELAS RURALES Y VIVIENDAS DE MAESTROS. PLAN NACIONAL DE CONSTRUCCIONES ESCOLARES (VOLUMNE II) PROYECTOS TIPO DE ESCUELAS GRADUADAS- 

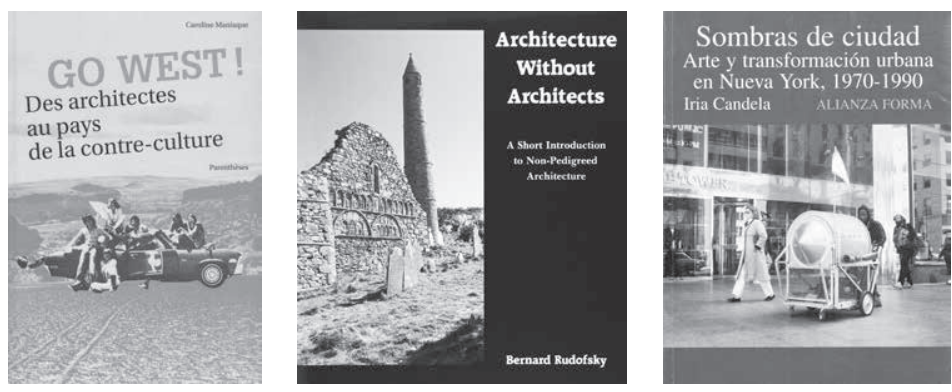

PPA N18: Caroline Maniaque: GO WEST! DES ARCHITECTES AU PAYS DE LA CONTRE-CULTURE - Bernard Rudofsky: ARCHITECTURE WITHOUT ARCHITECTS. A SHORT INTRODUCTION TO NON-PEDIGREED ARCHITECTURE - Iria Candela: SOMBRES DE CIUDAD. ARTE Y TRANSFORMACIÓN URBANA EN NUEVA YORK 1970-1990
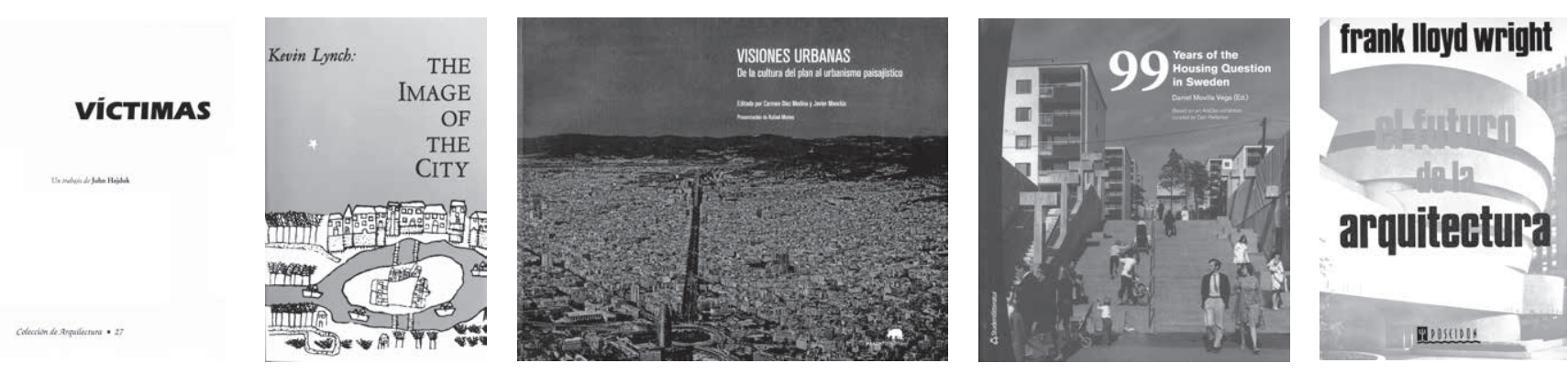

PPA N19: John Hejduk: VíCTIMAS - Kevin Lynch: THE IMAGE OF THE CITY - Carmen Díez Medina; Javier Monclús Fraga (eds): VISIONES URBANAS DE LA CULTURA DEL PLAN AL URBANISMO PAISAJÍSTICO / PPA N20: Daniel Movilla VEGA (Ed): 99 YEARS OF THE HOUSING QUESTION IN SWEDEN - Frank Lloyd Wright: EL FUTURO DE ARQUITECTURA
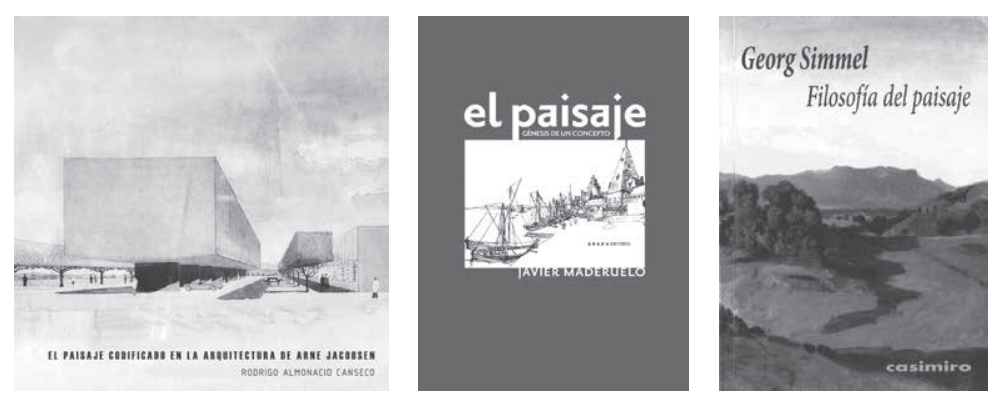

PPA N21: Rodrigo Almonacid Canseco: EL PAISAJE CODIFICADO EN LA ARQUITECTURA DE ARNE JACOBSEN - Javier Maderuelo: EL PAISAJE. GÉNESIS DE UN CONCEPTO - Georg Simmel: FILOSOFÍA DEL PAISAJE 
Y SOUTO DE MOURA / LIVING TERRACES: FROM REUSE IN TRADITIONAL ARCHITECTURE TO CÉSAR MANRIQUE AND SOUTO DE MOURA'S WORK WITH TIME. Francisco Javier Castellano Pulido • ESTRATEGIAS TERRITORIALES INTEGRALES PARA LA PUESTA EN VALOR DE PAISAJE CULTURAL AGRÍCOLA. LA RIBEIRA SACRA, GALICIA, ESPAÑA/COMPREHENSIVE TERRITORIAL STRATEGIES TO ENHANCE THE AGRICULTURAL-CULTURAL LANDSCAPE. RIBEIRA SACRA, GALICIA, SPAIN. Susana lópez Varela • PAISAJES DE ALTURA: lOS ANDENES DEL DISTRITO DE CABANA, VALLE DEL SONDONDO, PERÚ / HIGH LANDSCAPES: THE ANDENES OF THE DISTRIT OF CABANA, SONDONDO VALLEY, PERU. SOnia Delgado Berrocal • COLTIVARE I TERRAZZAMENTI AI PIEDI DEL MONTE BIANCO. LA "VITICOLTURA EROICA" DI MORGEX / CULTIVATING THE TERRACES AT THE FOOT OF MONT BLANC. THE "HEROIC VITICULTURE" OF MORGEX. Beatrice Agulli - SIAH DAREH. TERRAZAS Y PAISAJE EN ABBAS KIAROSTAMI / SIAH DAREH. TERRACES AND LANDSCAPE IN ABBAS KIAROSTAMI. Pablo López Santana • FRANK LLOYD WRIGHT. TRABAJAR LA TIERRA PARA UN PAISAJE SIMBIÓTICO / FRANK LLOYD WRIGHT. EARTHWORK FOR A SYMBIOTIC LANDSCAPE. José María Jové Sandoval • ROGELIO SALMONA Y LA CONSTRUCCIÓN DEL LÍMITE. DIÁlOgOS ENTRE TOPOGRAFÍA Y PAISAJE / ROGELIO SALMONA AND THE CONSTRUCTION OF LIMITS. DIALOGUES BETWEEN TOPOGRAPHY AND LANDSCAPE. Clara Mejía Vallejo; Ricardo Merí de la Maza • RESEÑAS BIBLIOgRÁFICAS • RODRIGO ALMONACID CANSECO: EL PAISAJE CODIFICADO EN LA ARQUITECTURA DE ARNE JACOBSEN . Carlos Santamarina-Macho • JAVIER MADERUELO: EL PAISAJE. GÉNESIS DE UN CONCEPTO. Victoriano Sainz Gutiérrez • GEORG SIMMEL: FILOSOFÍA DEL PAISA JE. Esther Mayoral Campa.

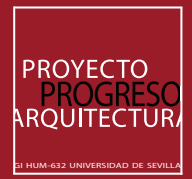
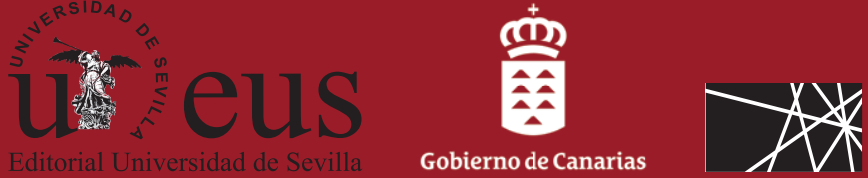